\title{
A Universal Definition of 'Domestication' to Unleash Global Animal Welfare Progress
}

\author{
Margot Simone Marcelle Décory \\ MSc Animal Law and Society, Autonomous University of Barcelona, Spain \\ MSc European Animal Management, University of Wageningen, the Netherlands
}

Received: February 2019

Accepted: March 2019

\begin{abstract}
Recommended citation. DÉCORY, M.S.M., A Universal Definition of 'Domestication' to Unleash Global Animal Welfare Progress, dA. Derecho Animal (Forum of Animal Law Studies) 10/2 (2019) - DOI https://doi.org/10.5565/rev/da.424
\end{abstract}

\begin{abstract}
This article proposes to establish a universal definition of the phenomenon of Domestication. Included in this phenomenon are, inter alia, the definitions of tame, domesticated or wild animals. Most of us intuitively think that wild and domesticated animals are easy to differentiate. But when it comes to giving measurable criteria to accurately discriminate species, there is today no consensus nor tool available. It has become a considerable gap considering that nowadays, challenges related to animal matters require international or global solutions which are only implementable through collaborations across the board and at all scales. However, without accurate and common definitions, those collaborations are rendered impossible. In this research, the etymology and definitions of the phenomenon of Domestication are considered, followed by its evolution across the literature. Are then examined the existing lists of domesticated species. Finally, the use of the concept of this phenomenon is looked at in laws at different scales and through international organisations, highlighting important discrepancies or even contradictions. The result of this research is the ascertainment that adopting a universal definition of the phenomenon of Domestication is absolutely paramount in order to progress on all animal-related matters. These observations and sources are then analysed in order to build the final part of this article: a proposal, aiming at giving an example of what the solution could look like.
\end{abstract}

Keywords: Proposal for Universal Definitions; Science of Evolution; Phenomenon of Domestication.

Resumen - Una Definición Universal de 'Domesticación' para Desencadenar el Progreso Mundial del Bienestar Animal

Este artículo propone establecer una definición universal del fenómeno de la domesticación. En este fenómeno se incluyen, entre otras, las definiciones de animales domesticados, domesticados o salvajes. La mayoría de nosotros intuitivamente pensamos que los animales salvajes y domesticados son fáciles de diferenciar. Pero cuando se trata de dar criterios medibles para discriminar con precisión a las especies, hoy no hay consenso ni herramienta disponible. Se ha convertido en una brecha considerable considerando que en la actualidad, los desafíos relacionados con los animales requieren soluciones internacionales o globales que solo se pueden implementar a través de colaboraciones en todos los ámbitos y en todas las escalas. Sin embargo, sin definiciones precisas y comunes, esas colaboraciones son imposibles. En esta investigación, se consideran la etimología y las definiciones del fenómeno de la domesticación, seguidas de su evolución en la literatura. Luego se examinan las listas existentes de especies domesticadas. Finalmente, el uso del concepto de este fenómeno se analiza en leyes a diferentes escalas y a través de organizaciones internacionales, destacando discrepancias importantes o incluso contradicciones. El resultado de esta investigación es la constatación de que adoptar una definición universal del fenómeno de la Domesticación es absolutamente primordial para avanzar en todos los asuntos relacionados con los animales. Estas observaciones y fuentes se analizan para construir la parte final de este artículo: una propuesta, con el objetivo de dar un ejemplo de cómo podría ser 
la solución.

Palabras clave: Propuesta de Definiciones Universales; Ciencia de la evolución; Fenómeno de la domesticación.

\section{Definitions used in this article:}

'Group' is used instead of 'species' or 'sub-species' when judged more accurate and is defined as: individuals of a same species or sub-species, or, a whole sub-species or species.

'Environment' is defined as any influence from humans and/or the living conditions humans impose on animals.

\section{Introduction}

Most of us intuitively think that wild and domesticated animals are easy to differentiate. But when it comes to giving measurable criteria to accurately discriminate species, there is today no consensus nor tool available.

This observation is made by professionals and countless publications. In the report "The welfare of wild animals in travelling circuses" made in 2016 by the Welsh Government ${ }^{1}$, experts and organisations around the world were consulted and one conclusion of the report was that "There is a lack of clarity as to what constitutes a domesticated animal, a wild species, a travelling circus, a mobile zoo, and performance. This leads to inconsistencies in which pieces of legislation apply to which species and in which circumstances."

Also in 2016, the World Wildlife Crime Report "Trafficking in protected species" from the United Nations Office on Drugs and Crime ${ }^{2}$ indicated that "virtually every country in the world plays a role" in wildlife crime.

Challenges related to animal matters all require international or global solutions which are only implementable through international collaborations. However, without accurate and common definitions, better policy and enforcement to improve animal welfare and protection is impossible.

\section{Etymology and Dictionaries}

The definition of 'domestication' evolves over time, influenced by cultural, linguistic, scientific or economic parameters. Today, stakeholders of the animal sector, from scientists to policy makers, have different approaches, interests and goals, and thus create context-specific definitions.

This myriad of tailor-made definitions leads to a confusion on the meaning of 'domestication', which can be observed in legislations, hindering progress in animal, human and nature protection.

The etymology ${ }^{3}$ and definitions ${ }^{4}$ of 'domesticate/d' associate it with the act of 'taming' animals ensuring they adapt to home life, possibly within a family. Domestication ${ }^{5}$ is "taming an animal and keeping it" indicating a continuity over time with a notion of control ${ }^{6}$.

Definitions include dogs, sheep and cattle as examples but 'other domesticated animals' are specified in none of the dictionaries.

Etymologically ${ }^{7}$ and across languages 'domestic' means "belonging to the household" or serving in a house.

\footnotetext{
${ }^{1}$ DORNING J., HARRIS S., PICKETT H., The welfare of wild animals in travelling circuses (2016), https://www.ispca.ie/uploads/The_welfare_of_wild_animals_in_travelling_circuses.pdf

${ }^{2}$ UNODC, World Wildlife Crime Report - Trafficking in protected species, United Nations Office on Drugs and Crime (2016), https://www.unodc.org/documents/data-and-analysis/wildlife/World_Wildlife_Crime_Report_2016_final.pdf,

${ }^{3}$ Online Etymology Dictionary, search keyword: domesticate, http://www.etymonline.com

${ }^{4}$ Online Oxford Dictionaries, search keyword: domesticated, http://www.oxforddictionaries.com/definition

${ }^{5}$ Online Oxford Dictionaries, search keyword: domestication, http://www.oxforddictionaries.com/definition

${ }^{6}$ Online Collins Dictionary, search keyword: domesticated, http://www.collinsdictionary.com

${ }^{7}$ Online Etymology Dictionary, search keyword: domestic, http://www.etymonline.com

40 Derecho Animal. Forum of Animal Law Studies, vol. 10/2
} 
The term 'domestic' may be defined as the act of existing or occurring inside a particular country ${ }^{8}$, in opposition to 'foreign' or 'international'. In this case, it opposes 'exotic'.

It can also be defined" as "of or involving the home or family", "enjoying or accustomed to home or family life", "bred or kept by man as a pet or for purposes such as the supply of food" or "not wild and is kept either on a farm to produce food or in someone's home as a pet". In this case, it opposes 'wild'.

From those definitions could be understood that 'domestic' animals refers to any animal kept by humans while 'domesticated' animals have been kept, tamed and bred by humans until attaining a degree of accustomization or even a taste for life in captivity with humans. Constantly using those terms as synonyms aggravate the confusion.

\section{Evolution of Knowledge and Concept}

While domestication may simply be defined ${ }^{10}$ as "becoming accustomed to the household", Darwin ${ }^{11,}$ 12 and others stated that domestication is the process through which "man selects varying individuals, sows their seeds, and again selects their varying offspring" which according to him represents "an experiment on a gigantic scale".

Some groups of animals may present traits making them more or less prone to domestication. Scientists have identified distinct pre-adaptive traits, making those groups more prone to domestication. Price ${ }^{13}$ has for example established a table listing behavioural characteristics called "Behavioral characteristics considered favorable and unfavorable for the domestication of vertebrate animals" while Gepts ${ }^{14}$ listed genetically preadaptive traits for animals and plants.

Darwin ${ }^{15}$ had discovered that mammals having gone through domestication then possessed heritable traits. This set of post-adaptive traits, sometimes called the Domestication Syndrome, is characterised by the fact that domesticated groups display "behavioral, physiological, and morphological traits not observed in their wild forebears"16, 17. The behavioural, physiological and morphological traits will here referred to as the "3 Categories (3C) of Changes". Examples of post-adaptive traits (lists non-exhaustive) are presented in Figure 1.

\footnotetext{
${ }^{8}$ Online Oxford Dictionaries, search keyword: domestic, http://www.oxforddictionaries.com/definition

${ }^{9}$ Online Collins Dictionary, search keyword: domestic, http://www.collinsdictionary.com

${ }^{10}$ CASSIDY R., MULLIN M., Where the Wild Things Are Now: Domestication Reconsidered (Berg 2007)

${ }^{11}$ DARWIN C., The Variation of Animals and Plants under Domestication (London 1868)

${ }^{12}$ DARWIN C., The origin of species (London 1859)

${ }^{13}$ PRICE E.O., Animal domestication and behaviour (New York 2002)

14 GEPTS P., Plant and Animal Domestication as Human-Made Evolution, University of California, Davis, http://www.plantsciences.ucdavis.edu/gepts/Gepts\%20AIBS-NABT\%20Chicago\%202004.pdf

${ }^{15}$ See supra, note 11 and note 12

${ }^{16}$ See supra, note 13

17 WILKINS A.S., WRANGHAM R.W., TECUMSEH FITCH W., The "Domestication Syndrome" in Mammals: A Unified Explanation Based on Neural Crest Cell Behavior and Genetics, 197/3 Genetics (2014) 795-808
} 


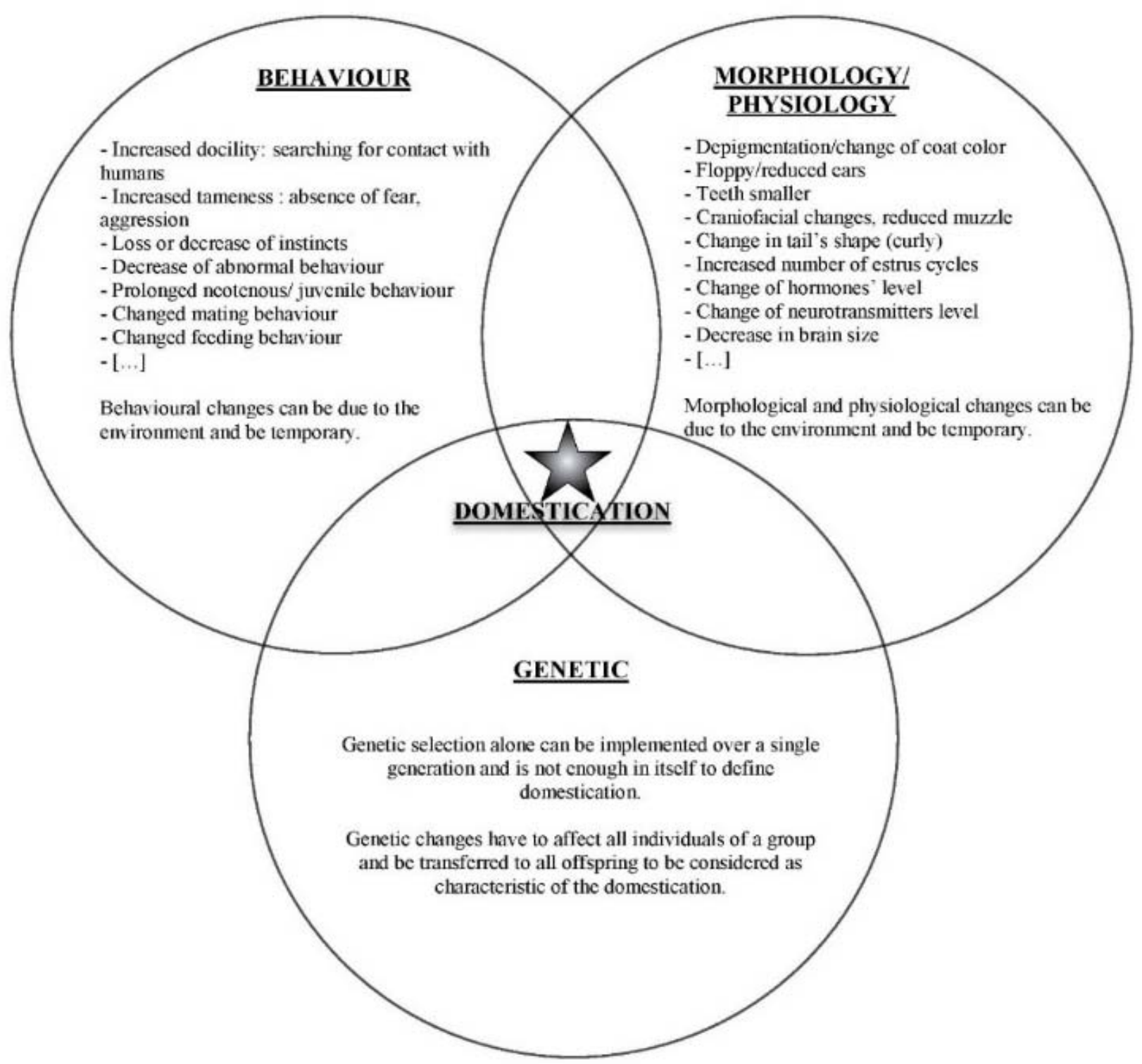

Figure 1 (created by the author): Illustration of the 3 Categories (3C) of Changes: Behaviour, Morphology/Physiology and Genetic

Domesticated groups displayed pre-adaptive (pre-domestication) traits predisposing them to domestication and show post-adaptive (post-domestication) traits if they have undergone domestication.

However, a domesticated group "has undergone genetic changes that alter its appearance, physiology, and, consequently, its behaviour" 18,19 . Hence, groups displaying pre-adaptive traits and only some postadaptive traits not affecting the $3 \mathrm{C}$ of Changes might never become domesticated. For Price ${ }^{20}$ and Warwick ${ }^{21}$, some groups are 'programmed' to being wild, meaning they are genetically highly precocious or 'hard-wired' to being wild. These hard-wired groups "include the reptiles and probably other 'ectothermic' ('coldblooded') animals such as the invertebrates, fishes and the amphibians" 22 .

Some genetic modifications can be easily controlled by humans, thus, observed alone, they do not attest of the domestication of a group. Observing behavioural, morphological, physiological or genetic changes or a combination of only some of those parameters could therefore be considered insufficient: the domestication process seems to imply a modification of all of those parameters.

18 PRICE E.O., Behavioral development in animals undergoing domestication, Department of Animal Science, University of California, Davis, CA 95616-8521 USA (1999)

${ }^{19}$ RICKER J.P., SKOO L.A., HIRSCH J., Domestication and the behavior-genetic analysis of captive populations, Applied Animal Behaviour Science, 18 (1987) 91-103

${ }^{20}$ PRICE E.O., Behavioral aspects of animal domestication, Quarterly Review of Biology, 59 (1984) 1-32

${ }^{21}$ WARWICK C., Reptilian ethology in captivity: observations of some problems and an evaluation of their aetiology, Applied Animal Behaviour Science, 26 (1990) 1-13

${ }^{22}$ See supra, note 21

42 Derecho Animal. Forum of Animal Law Studies, vol. 10/2 


\section{Lists of Domesticated 'Species'}

\section{a. Classification}

Definitions are often made for management purposes regarding for example trade or diseases prevention.

There are as many lists of 'domesticated species', as there are of definitions. As definitions depend on the context and purpose for which they are created, so are the corresponding lists. Price ${ }^{23}$ states:

1. The "domestication process is difficult to avoid when animals are brought into captivity. Most captive-reared wild animals will express certain aspects of the domestic phenotype simply by being reared in captivity. The application of artificial selection together with the effects of natural selection in captivity can greatly accelerate the domestication process."

2. "Man has domesticated relatively few animal species, either by choice or because of failure to provide a captive environment that meets the minimal requirements for successful reproduction".

3. "The title of the book, Animal Domestication and Behavior, may seem a bit misleading to some readers, since so much of the book is devoted to the topic of the management of captive animals, whether domesticated or not".

4. While species becoming captive-reared and captive-bred might be considered in the first step towards domestication, it does not imply that they will (soon or ever) become domesticated. Definitions used solely for management purposes cannot be used to properly define the domestication status of those groups.

\section{b. Single use definitions}

In "The welfare of wild animals in travelling circuses" 24 definitions are made "for purpose of the review". In that report "non-domesticated animals were defined as "a member of a species that is not normally domesticated in the British Islands; that is to say, a species whose collective behaviour, life cycle or physiology remains unaltered from the wild type despite their breeding and living conditions being under human control for multiple generations". This definition derives from the Zoo Licensing Act 1981 and is the one used in an earlier review of Wild animals in travelling circuses".

This definition targets groups occurring in the British Islands, avoiding questions such as the existence of locally domesticated groups or considerations based on culture or economy but it does not allow to identify domesticated and non-domesticated groups.

For Price ${ }^{25}$, domestication happens "by some combination of genetic changes occurring over generations and environmentally induced developmental events recurring during each generation" but here there is not mentioned of the fact that changes should affect all offspring of the group over generations.

Collective behaviour, life cycle and to some extent the physiology of a group could be shaped by environmental conditions alone and it would then not imply domestication, or lack thereof.

\section{c. Taxonomic complexity}

Darwin ${ }^{26,27}$ said "In the case of most of our anciently domesticated animals and plants, I do not think it is possible to come to any definite conclusion, whether they have descended from one or several species".

However, in 2012 Dr. J. Clutton-Brock ${ }^{28}$ gave a list of 'domestic' animals and their wild progenitors. According to that list, there are 29 domesticated 'species' including mammals, birds, fish and insects of which 18 have changed taxonomic names.

The complexity of the phylogeny has a direct impact on the taxonomy and as the phylogeny is not always clear or known, there is no consensus on a reliable and common taxonomic system.

\footnotetext{
${ }^{23}$ See supra, note 13

${ }^{24}$ See supra, note 1

${ }^{25}$ See supra, note 13

${ }^{26}$ See supra, note 11

${ }^{27}$ See supra, note 12

${ }^{28}$ CLUTTON-BROCK J., Animals as Domesticates, Michigan State University Press (2012)
} 
The longer the relationship between humans and a group, the higher the probability is that this group is considered domesticated. Nevertheless, in principle, groups can be captive-bred forever without ever becoming domesticated, all depends on the definition given to 'domestication'.

For example, there is no consensus on whether a domesticated group should be considered a new species or sub-species or if it should change name. Changing the name would show that the domesticated group has evolved in a new species while keeping the same name but adding 'domestic' (often found in literature, misused for 'domesticated') would make visible the ancestors' lineage ${ }^{29,30}$.

In conclusion, taxonomic changes are probably a better indicator of time rather than domestication. They represent unsuitable criteria to determine the domestication status of a group.

\section{d. Semi-domestication}

In the following paragraph, Wikipedia is analysed as one the most used free online encyclopedia around the world, therefore accessible to all stakeholders across sectors.

Wikipedia's list of domesticated species ${ }^{31}$ includes species which might be considered in the process of being domesticated, creating a "degree and type of domestication".

Dogs are described as "tame (with exceptions), significant physical changes, probably significant behavioural changes." Dogs' domestication status is the main, not to say the only consensus existing today across the literature as they are believed to have been the first group to become domesticated. Therefore, this description reveals major approximations.

The terms "semi-domesticated", "routinely captive-bred" and "domestication status unclear" are used and Wikipedia seems to define 'semi-domesticated' by "captured from wild and tamed".

Domestication implies the adaptation of wild groups to humans but also to the environment that they (humans) provide. The process is not linear and every group adapts and evolves in a singular way when kept in captivity, depending on the conditions provided (environment, food, and many more parameters) and groups-specificities.

Discriminating groups based on the fact that they are kept in captivity might be practical for trading or legal purposes, but does not reflect accurately the domestication's status of a group.

\section{Laws and International Organizations}

\section{a. International Laws}

The Convention on Biological Diversity ${ }^{32}$ of the United Nation from 1992 encompasses 196 Parties across the world. Article 2 establishes the Use of Terms set "for the purpose of this Convention" including: "“Domesticated or cultivated species" means species in which the evolutionary process has been influenced by humans to meet their needs". The definition does not give clarity on how those changes have occurred or in what they have resulted.

Even though the international Convention on International Trade in Endangered Species of Wild Fauna and Flora of 1973 (CITES) is not a law as such, it is the most used and enforced international text. It does not contain a definition of 'wild' but contains specifications to define captive-bred species in Resolution Conf. 10.16 (Rev. $)^{33}$. It can be noted that the eight taxa mentioning "domesticated forms" or "specimen of domesticated form" only concern mammals.

\section{b. European Laws}

The Lisbon Treaty of 2007 (Article 13) 34 acknowledged the scientific advances by stating that animals are sentient beings, not objects. European countries are progressively aligning their legislations.

In 2013, Regulation (No 576/2013) s5 $^{35}$ on non-commercial movement of pet animals, had only a definition for 'pet animal': “"pet animal' means an animal of a species listed in Annex I accompanying its

\footnotetext{
${ }^{29}$ See supra, note 13

${ }^{30}$ CLUTTON-BROCK J., A Natural History of Domesticated Mammals, Cambridge Univ. Press, Cambridge, UK (1999)

${ }^{31}$ Wikipedia, The Free Encyclopedia, List of domesticated animals https://en.wikipedia.org/wiki/List_of_domesticated_animals

${ }^{32}$ Convention on Biological Diversity (5 June 1992), https://www.cbd.int/doc/legal/cbd-en.pdf

${ }^{33}$ CITES, Resolution Conf. 10.16 (Rev.), https://www.cites.org/eng/res/10/10-16C15.php

${ }^{34}$ Consolidated version of the Treaty on the Functioning of the European Union, Official Journal C 326, 26/10/2012, P. $0001-0390$

(13 December 2007)

${ }^{35}$ Regulation (EU) No 576/2013 of the European Parliament and of the council of 12 June 2013 on the non-commercial movement of pet animals and repealing Regulation (EC) No 998/2003

44 Derecho Animal. Forum of Animal Law Studies, vol. 10/2
} 
owner or an authorised person during non-commercial movement, and which remains for the duration of such non-commercial movement under the responsibility of the owner or the authorised person".

According to this definition animals are only considered pets when they are in Annex I, accompanied by their owner/keeper and transported.

The Animal Health Law Regulation $(2016 / 429)^{36}$ of 2016 regarding transmissible animal diseases and amending and repealing certain acts in the area of animal health gives definitions in Article 4 as follows:

"Kept animals: "animals which are kept by humans, including, in the case of aquatic animals, aquaculture animals",

Wild animals: "animals which are not kept animals",

Pet animal: "a kept animal of the species listed in Annex I which is kept for private non-commercial purposes"”.

Whether animals are wild or domesticated does not influence if they are considered by the EU law as 'kept', 'wild' or 'pet' animals.

This Manichean vision of animals being 'kept/not kept', may have been adequate at the inception of the EU but is today dangerously insufficient. The health of humans, farm animals, pets and wild animals are linked ${ }^{37}$. The One Health concept states: "Considering health and welfare together - because of the interconnections of human, animal and environmental factors - helps to describe context, deepens our understanding of the factors involved, and creates a holistic and solutions-oriented approach to health and welfare issues." $" 38$.

Animal welfare being linked to animal domestication status and health, it can be assumed that the keeping of animals depending on their domestication status has an indirect consequences on humans' health. Thus, that parameters should urgently be included in the law-making process, matching the reality of the animals' uses.

\section{c. European Member States Laws}

The European institutions and legal texts establish a legal framework and guidelines for the Member States. Subsequently, member states are responsible for adopting and enforcing those at national level. Yet, as European laws only deal with animals linked to the trade without setting clear definitions, member states adopt definitions according to their own knowledge, culture, trade, political will, economic interests and more.

Consequently, there are pretty much as many definitions as there are member states ${ }^{39}$. Those national definitions too, use indifferently 'domestic' and 'domesticated' and are often inaccurate, inefficient and impossible to enforce. Examples of definitions:

- Cyprus - Law for the protection, health and welfare of animals, 1994 - 'wild' animals: an animal which due to its nature is destined to live in a free state without restriction or guidance imposed by man,

- Lithuania - Law on the Care, Welfare and Use of Animals, amended 2001 - 'domesticated' animals: all of the traditionally tamed (domesticated) animals,

- Austria - Animal Protection Act, 2004 - 'wild' animals: all animals except domestic and pet animals.

\section{d. International Organizations} $\operatorname{Code}^{40}$ :

The World Organisation for Animal Health (OIE) uses definitions of the OIE Terrestrial Animal Health

- "Animal: a mammal, bird or bee."

\footnotetext{
${ }^{36}$ Animal Health Law - Regulation (EU) 2016/429 of the European Parliament and of the Council of 9 March 2016 on transmissible animal diseases and amending and repealing certain acts in the area of animal health

${ }^{37}$ One Health Initiative, http://www.onehealthinitiative.com/

${ }^{38}$ PINILLOS, RG., APPLEBY, MC., MANTECA, X., SCOTT-PARK, F., SMITH, C., VELARDE, A., One Welfare - a platform for improving human and animal welfare, Veterinary Record 179 (2016) 412-413

${ }^{39}$ Eurogroup for Animals, Analysis of national legislation related to the keeping and sale of exotic pets in Europe (July 2013)

${ }^{40}$ OIE, The OIE Terrestrial Animal Health Code, Glossary (2017)
} 
- "Captive wild animal: an animal that has a phenotype not significantly affected by human selection but that is captive or otherwise lives under direct human supervision or control, including zoo animals and pets."

- "Feral animal: an animal of a domesticated species that now lives without direct human supervision or control."

- "Wild animal: an animal that has a phenotype unaffected by human selection and lives independent of direct human supervision or control."

- "Wildlife: feral animals, captive wild animals and wild animals."

The IUCN Guidelines for Using the IUCN Red List Categories and Criteria ${ }^{41}$ states that "This delineation of 'wild' from 'not wild' roughly corresponds to the difference between "lightly managed species" and "intensively managed species" as defined by Redford et al (2011)"42.

In a statement on wild animals used in circuses ${ }^{43}$ from 2015, Eurogroup for Animals states that tamed or domesticated animals are not to be mistaken, defining 'domesticated' as: "Animals on species level which are result of long-lasting selective breeding process. Over many thousands of years, only few species have been domesticated, others may not become so even after many generations of selective breeding. An animal species is considered domesticated when it has undergone genetic changes that alter its appearance, physiology, and, consequently, its behavior. This lengthy process requires selection for specific traits for many generations on row, which can mean many dozens of years or even centuries, depending on the strictness of selection and reproductive rate of the species concerned."

Laws at all scales and international organizations, use different logics and definitions.

\section{Proposal: A Universal definition}

To face the urgent need for universal definitions, a proposal is presented for reflexion and consideration. The definitions given in Table 1 build the concept of the process of domestication illustrated Figure 2. This proposal is meant as an invitation and a call to find a consensus for the greater good of animals, humans and nature.

\section{DEFINITIONS AND CONCEPT}

Table 1 (created by the author): Definitions linked to the concept of Domestication

\section{WILD ANIMAL}

Wild animals originally lived and bred in their natural environment and had not been influenced by humans.

In captivity, wild individuals and groups might display changes in their behaviour, genetic and/or physiology/morphology compared to their ancestors living in nature, due to proximity with humans, living conditions and/or selective breeding.

Wild individuals and groups may become tame, while only groups may become domesticated.

Wild animals might be found only in captivity, having disappeared in nature, they remain nonetheless wild.

A wild animal belongs to a wild group and can be found in nature and/or in captivity.

A wild group has traits from its ancestors/conspecifics originally found in nature, such as behaviours and physiological needs. A wild group hasn't undergone domestication.

Particular case: A wild group might have gone through domestication and feralisation to become a new wild group.

\footnotetext{
${ }^{41}$ IUCN, Guidelines for Using the IUCN Red List Categories and Criteria, Version 13 (March 2017)

${ }^{42}$ REDFORD K.H., AMATO G., BAILLIE J., BELDOMENICO P., BENNETT E.L., CLUM N., COOK R., FONSECA G., HEDGES S., LAUNAY F., LIEBERMAN S., MACE G.M., MURAYAMA A., PUTNAM A., ROBINSON J.G., ROSENBAUM H., SANDERSON E.W., STUART S.N., THOMAS P., THORBJARNARSON J., What does it mean to successfully conserve a (vertebrate) species?, BioScience 61 (2011) 39-48

${ }^{43}$ Eurogroup for Animals, Statement on ethological needs and welfare of wild animals in circuses (September 2015)

46 Derecho Animal. Forum of Animal Law Studies, vol. 10/2
} 


\section{DOMESTIC ANIMAL}

'Domestic' should not be confused with 'domesticated'. 'Domestic' is what belongs to the house, what is kept.

Individuals and groups of wild, tame, domesticated or feral animals can be domestic as this term only indicates that the animals are maintained under human control, usually in a farm, garden, house or equivalent.

A domestic animal is kept in captivity by humans, regardless if it is a wild, tame, domesticated or feral animal.

\section{TAME/TAMED ANIMAL}

'Tamed' is often confused with 'domestic' or 'domesticated', while it should only apply to wild or feral individuals or groups. A tame animal can be a wild animal taken from nature, a first-generation offspring of captive-bred wild parents taken from nature or an animal descending several generations of captivebred wild animals.

Taming starts by keeping wild or feral animals in captivity and physically subduing them to accept humans' proximity and their environment. It leads to behavioural changes and also potentially to genetic and/or physiological/morphological modifications of an individual or group.

Taming can be considered the first step towards domestication once animals are maintained in captivity, only when it occurs for a group, as a tame individual cannot lead to a domesticated group.

Taming reduces the natural avoidance of humans and increases a friendliness towards humans. When kept in captivity, wild/feral tamed animals should have a better welfare than wild/feral untamed animals.

A tame animal is a wild or feral animal kept in captivity, which may consequently have seen its behaviour and potentially other of its characteristics (genetic, morphology/physiology) evolve.

The changes triggered by the living conditions and contact with humans should make the tame animal less fearful for humans and more adapted to the environment, which should decrease the need to attack and the need to cope with the living conditions through the development of stereotypes.

A tame animal remains wild or feral, its behaviour remains unpredictable and its needs can't always be fulfilled in captivity.

\section{PRE-ADAPTIVE TRAITS}

Pre-adaptive traits are characteristics (behavioural, physiological or else) observed in all individuals of all generations of a wild group. They predispose groups to become tame and then potentially domesticated. Groups lacking pre-adaptive traits are unlikely to ever become tame or domesticated however, the display of pre-adaptive traits is no guarantee of future domestication either. Groups displaying pre-adaptive traits might never become tame or domesticated either.

Pre-adaptive traits observed in all individuals of all generations of a wild group predispose to taming and domestication. They can concern behavioural, morphological, physiological or genetic traits. The combination of those traits is group-specific. Even though a group may display pre-adaptive traits, it might never become tame or domesticated.

\section{SEMI-DOMESTICATED ANIMAL}

The term 'semi-domesticated' is often used in place of 'captive', 'captive-bred', 'domestic', 'kept' or 'tame'.

Each group having its own way to react to captivity and to the process of taming and domestication, the use of 'semi-domesticated' is inaccurate and should be avoided.

A semi-domesticated animal is wrongfully described. The process of domestication is complex and group-specific, which does not allow the identification of when a group has gone through 'half' of it. It is advised to avoid using the term 'semi-domesticated'. 
The process of domestication goes through several steps (Cf. Fig. 2) which are group-specific. Moreover, the outcome of each domestication is also group-specific and there are as many by-products of domestication as there are domesticated groups. Yet both pre-adaptive and post-adaptive traits can be observed in domesticated groups.

A domesticated animal belongs to a domesticated group.

A domesticated group has undergone domestication.

Domestication of a group is a complex and multifactorial phenomenon affecting biological, behavioural and genetic processes in all individuals of this group and for several generations. Domestication is considered complete when all Domestication Characteristics (DC) of the Proposal Assessment Tool (PAT) are observed in all individuals of a group for several generations. The new group might be described as a new species or sub-species.

\section{POST-ADAPTIVE TRAITS / DOMESTICATION SYNDROME}

The initial selection of behaviour by humans led to the selection of hormones which itself led to additional 'collateral' selections. As hormones regulate every process of a living being, from the expression of genes at an early stage, to sexual behaviour, it follows that the literature acknowledges that there is a part of involuntary selection in the process of artificial selection. All post-adaptive traits and their expression are linked, they are constantly adapting and influencing each other, making the evolution of groups a permanent movement and evolution.

Post-adaptive traits are characteristics (behavioural, physiological/morphological or genetic) which have appeared in groups kept and maintained in captivity. Those changes can be due to contact with humans and/or with their environment. For domesticated groups, the full set of post-adaptive traits is groupspecific (behavioural, physiological/morphological and genetic), therefore neither the isolated observation of post-adaptive traits in a group, nor the observation of the set of post-adaptive traits only in individuals rather than in all offspring, can attest of domestication.

\section{STRAY ANIMAL}

'Stray' should not be confused with 'wild'. It is usually used to describe domestic or domesticated animals which have escaped human control (or been released). It can apply to both 'domestic wild' and 'domestic domesticated' animals, but it is usually used for domesticated animals found in nature (cats and dogs in particular).

'Stray', like 'domestic', expresses the location of an animal or group. Any wild, tame, domesticated or feral individual or group kept under human control, with or without controlled breeding, could be called 'stray' when found out of human control.

The identification of a wild or tame animal as stray will depend on the conditions and nature it is found in. If the animal is not native in that region, its identification as stray will be easier.

A stay animal is a wild, tamed, domesticated or feral individual which was kept under human control and has escaped or been released and is found without human supervision.

\section{FERAL ANIMAL}

Feralisation, or de-domestication can be seen as the reverse process of domestication and can only occur to groups. There is a notion of time hence of generations between 'stray' and 'feral'. After animals get back into nature they are considered stray and when they manage to re-adapt, survive and reproduce in nature on their own, they may be considered feral.

The difference between 'feral' and 'wild' is the $3 \mathrm{C}$ of changes anew observed. Feral groups eventually re-adapt to their environment, therefore their behaviour, genetic and morphology/physiology can again be modified, leading to a new group (which might again be described as species or sub-species).

Feral animals would have to undergo taming again to re-adapt to humans and their environment. 'Feral' is sometimes used as adjective for animals becoming 'desocialised' from humans, or for animals which 
have never become socialised or for groups which cannot be tamed nor/or domesticated. 'Feral' is an indication of non-domestication rather than an accurate description of the domestication status.

A feral animal belongs to a feral group.

A feral group was domesticated, has escaped (or been released) from human control, has survived, readapted and reproduced in nature without human control.

Feralisation is the reverse phenomenon to domestication. A group re-adapts to living in nature without human control. Changes in the group's behaviour, genetic and/or morphology/physiology may be observed leading to a new group (which might be described as species or sub-species). 


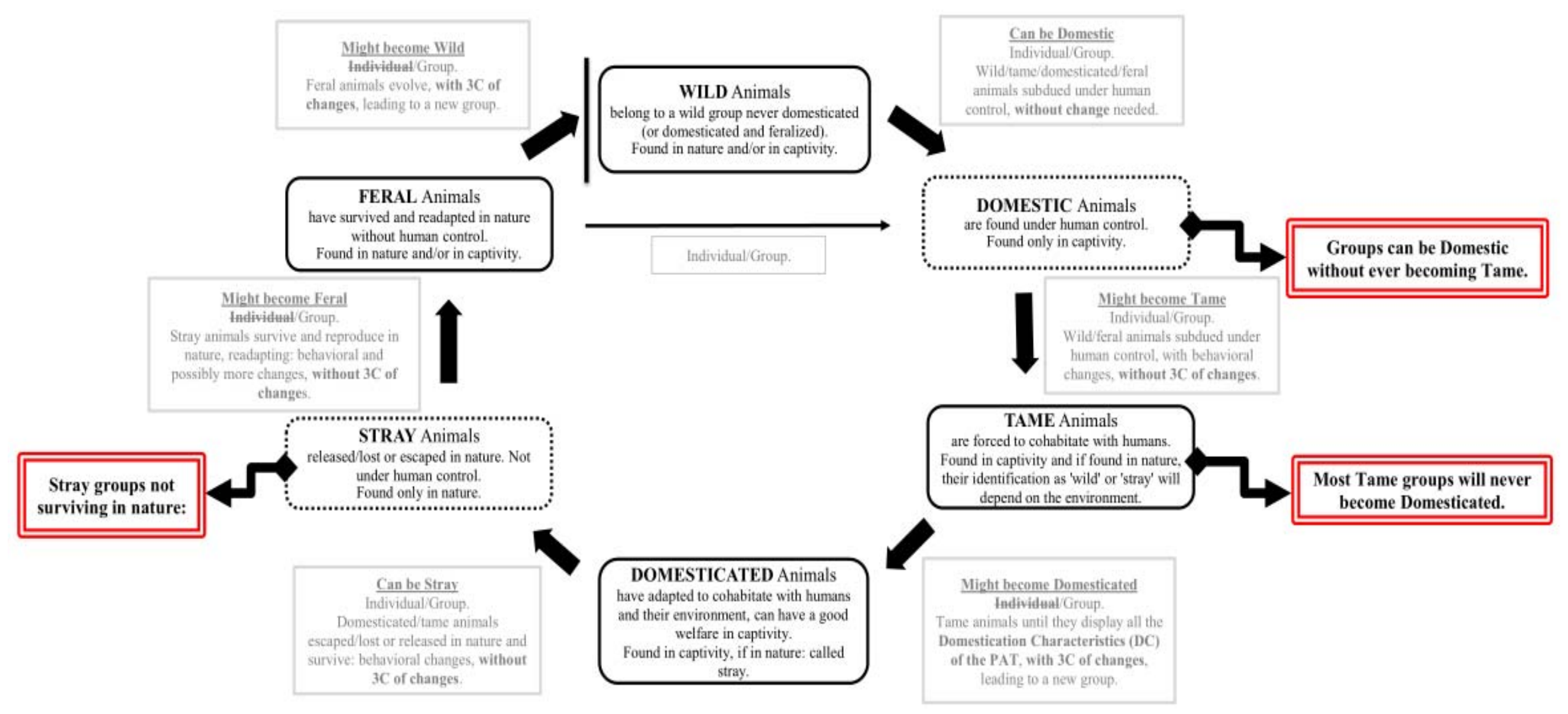

Figure 2 (created by the author): Concept of interconnected definitions forming the process of domestication 
All the definitions given in this proposal are connected and interdependent, meaning that it is possible to pass from one to another, directly or indirectly.

In Figure 2 'Individuals/Groups' highlights if the change from one status to another can be performed by individuals alone or not. As seen in the definitions, domestication, feralisation and becoming wild again cannot happen to individuals. The mention of " $3 \mathrm{C}$ of changes" indicated if the 3 categories of changes: behaviour, genetic and morphology/physiology are affected or not (see Figure 1). Some of those statuses and processes are mutually exclusive, which is illustrated by Figure 3.

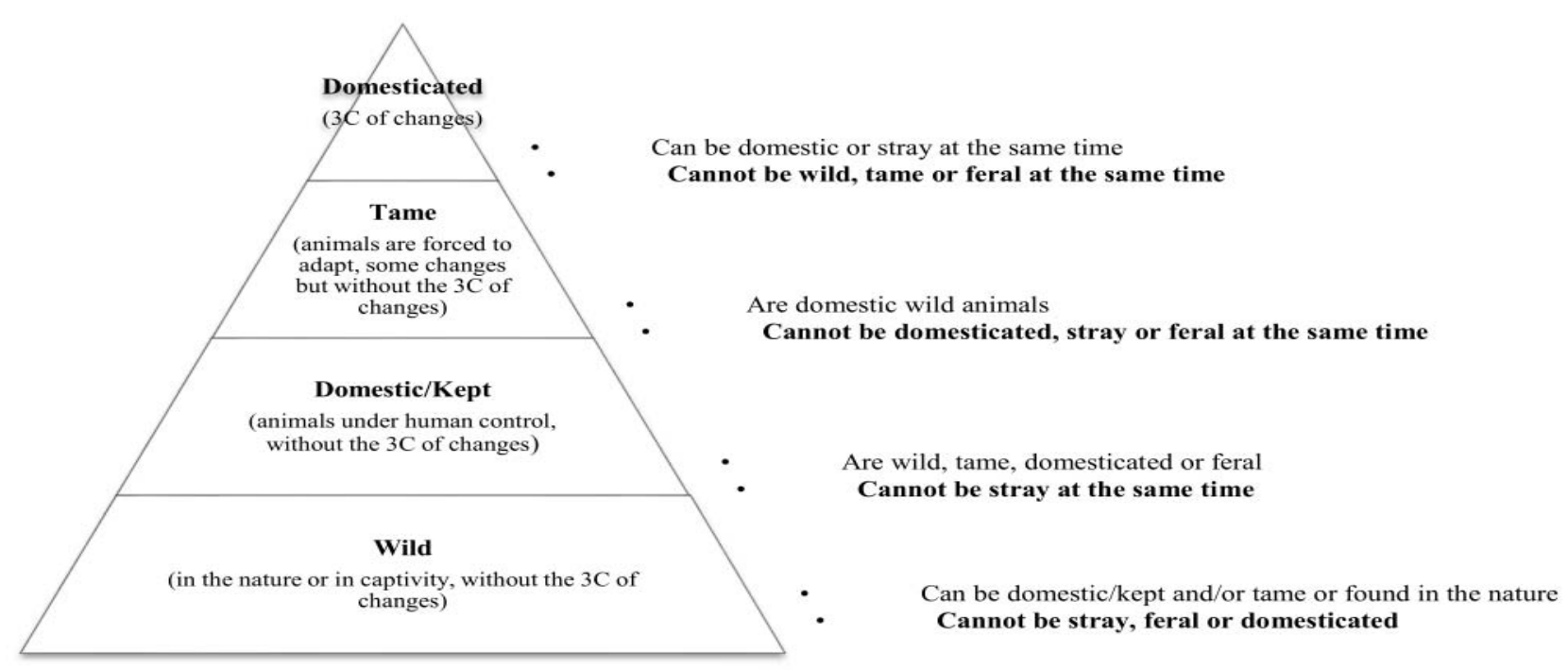

Figure 3 (created by the author): Mutually exclusive statuses

The definitions and concept proposed above are the base to discriminate groups. The Proposal Assessment Tool (PAT) presented in Table 2 gives an example of what could be a tool allowing the discrimination of domesticated groups.

\section{Proposal Assessment Tool}

Only the combination of all Domestication Characteristics (DC) of the PAT would allow to conclude on the domestication status of a group. If one DC is missing, the group remains considered wild, tame or feral.

\section{Table 2 (created by the author): Proposal Assessment Tool (PAT) of the process of Domestication}

\section{Domestication Characteristics (DC) of the considered group:}

1. Wild ancestors displayed pre-adaptive traits prior to being in contact with humans.

A set of at least 3 pre-adaptive traits needs to be observed in all individuals and all generations of the group considered.

2. Living conditions permanently controlled by humans without interruption for a minimum of 57 generations. 
The process of domestication can be localized in the world. Living conditions include e.g.: contact with humans, housing (temperature, humidity, light, space); waste and predation removal, veterinary care, diet, contact with other animals.

The threshold of 57 generations comes from a regression calculation based on the silver fox experimentation Even though the choice of this experiment as model is arbitrary, it is considered "one of the most impressive experiments in the history of evolutionary biology". The estimation of the number of generations needed to select a trait of interest (tameness) for $100 \%$ of the offspring, under intensive selection, is based on a linear analysis, and doesn't include many parameters which might make the reality of the process closer to a logarithmic progression. In the case of a logarithmic progression 184 generations would be needed to select that single trait. Therefore 57 generations is considered an underestimation due to the need to discriminate species.

3. Active artificial selection of a closed group maintained for at least 57 generations.

Active selection of traits of interest (behavioural, physiological, morphological or genetic). After 57 generations, occasional addition of animals, eggs or gametes can happen between wild/tame and domesticated animals to reinforce certain characters or avoid inbreeding, as long as the portion of wild characters added does not reverse the $3 \mathrm{C}$ of changes.

4. Set of at least 3 behavioural changes compared to the wild ancestors - post-adaptive traits.

Those behavioural changes are part of the $3 \mathrm{C}$ of changes, they must affect all individuals of the group and be transmitted to all offspring, reoccurring in each generation. They are independent from the living conditions at the time of the assessment.

5. Set of at least 3 genetic changes compared to the wild ancestors - post-adaptive traits.

Those genetic changes are part of the $3 \mathrm{C}$ of changes and must affect all individuals of the group and be transmitted to all offspring, reoccurring in each generation. They are independent from the living conditions at the time of the assessment.

6. Set of at least 3 physiological/morphological changes compared to the wild ancestors - post-adaptive traits.

Those physiological/morphological changes are part of the 3C of changes and must affect all individuals of the group and be transmitted to all offspring, reoccurring in each generation. They are independent from the living conditions at the time of the assessment.

7. Can have good welfare in captivity.

The Five Freedoms as described in the Brambell Report can be fulfilled in captivity. Animals looking for contact with humans. Absence of stereotypes (e.g. self-mutilation, apathy...) or any other behaviour or physical cue which would signal the need to cope with the environment/captivity. None of the DC should involve secondary consequences for the group (e.g. a change in oestrus rhythm should not trigger cannibalism over offspring).

8. Knowledge available on the group in the region where the group is considered for assessment for domestication. 
Qualitative and quantitative knowledge (science-based/peer-reviewed and practical knowledge) available to professionals and to the public on the traits and needs of the youngers and adults of the group. Those traits and needs include diet, optimal living conditions, natural living conditions in nature and natural behaviour of the wild ancestors, health specificities, risks to humans and other animals (zoonosis, parasites), mating behaviour, social structure, risk of invasiveness in the regional environment, diurnal/nocturnal rhythm, need for rest or movement, acreage of territory if relevant.

Knowledge of the ranking of priority of those characteristics for the group, for example if social contact is more important than diet or space to the group.

\section{Discussion - some reflexion points}

Humans need to be more critical on their assessment of the domestication as 'beneficial' or 'detrimental' to a group. Considering the progress of science on animal biology, health and welfare, domesticating new groups should depend on at least 2 factors: whether the group considered might ever become domesticated and whether humans consider it ethically reasonable in the sense of ethically justifiable.

Moreover, in a world witnessing the disappearance of wildlife in the last 10000 years ${ }^{44}$, shouldn't humans primarily try to protect and restore habitats instead of bringing more groups under human control?

Domestication and welfare are tangled as domestication is the process through which a group adapts to captive conditions and to humans. Domestication therefore testifies to the animals' suitability to be in captivity while maintaining a good welfare. However, wild and tame animals did not go through domestication, their natural, 'innate' behaviours have not been modified drastically; thus, one can wonder how a wild or tame animal, kept in captivity, could have a good welfare. Additionally, research on the risk factor in carnivore welfare ${ }^{45}$ showed that the bigger the home range size and daily travel distance of a group is, the bigger risk there is that the species will develop stereotypes and have high captive infant mortality. Therefore the definition of welfare as set by the Brambell report might be more adapted for captive domesticated animals than for captive animals in general.

Domestication is group-specific, can be local and a group does not necessarily have a single group as wild ancestors however, some groups might evolve, picking up characteristics enabling them to thrive in a world increasingly altered by humans without necessarily becoming domesticated.

One can consider that a group is affected from the moment it becomes captive, however this vision should have limitations. While it can be considered that most of the $3 \mathrm{C}$ of changes are reversible, the loss of instincts or physical traits might not be recoverable. Yet, the capacity animals have to change behaviour determines their "ability to survive and reproduce, both in captivity and when reintroduced into nature" 46 .

This tipping point remains unknown and should be carefully taken into account when deciding to keep a wild group in captivity for conservation purposes. Even though we probably do not have enough distance to assess that risk and no other option considering the alteration of nature, those modifications making a group less fit for survival in nature cannot be ignored.

While the process of domestication initially had an honourable goal such as providing food, humans have since learnt a great deal on animal welfare and cognition, recognizing animals as sentient beings. As a consequence, considering the huge constraints domestication implies, one can now grasp how long and painful the process probably is. Follows that if it is not a conscious and thought through decision to start the domestication of a given group, one should wonder if it should be considered unethical to allow its captivity? The same question applies to non-domesticated individuals or group kept in captivity isolated or for other purposes than domestication.

Choosing to tame and when possible domesticate animals should start by the identification of the possible welfare impairments for the group and the analysis of the justification and legitimacy of that decision.

If the use of such a heavy management is not for identified, legitimate and agreed upon purposes, humans shouldn't be keeping non-domesticated animals.

\footnotetext{
${ }^{44}$ SMIL V., Harvesting the Biosphere: The Human Impact, Population and Development Review, 37/4 (2011) 613-636 (DecEM BER), http://vaclavsmil.com/wp-content/uploads/PDR37-4.Smil_.pgs613-636.pdf,

${ }^{45}$ CLUBB R., MASON G.J., Natural behavioural biology as a risk factor in carnivore welfare: How analysing species differences could help zoos improve enclosures, Applied Animal Behaviour Science, 102/3 (2007) 303-328

${ }^{46}$ See supra, note 10
} 


\section{Conclusion}

Whether one sees domestication as "a process of capturing, enslaving, and breeding animals for our human purpose" 47 or as a willingness from both humans and animals to cohabit leading to a "mutually beneficial relationship" 48 , the current lack of a clear and universal definition is keeping stakeholders from collaborating efficiently and policy makers from making sensible and enforceable laws. Overall it hinders the progress of all matters related to animals, hence to humans and nature.

Domestication, animal welfare and health, human health and safety as well as the protection of nature are tangled and should therefore always be regarded together with moral and ethical considerations.

Recommendations :

1. Find a consensus on universal definitions.

2. Elaborate a tool such as the PAT allowing to discriminate domesticated groups.

3. Include moral and ethics in the way we use animals, taking into account their domestication status.

\section{References}

- BALYAEV D.K., Destabilizing selection as a factor in domestication (1978) http://evolocus.com/publications/belyaev1979.pdf

- BIDAU C.J., Domestication through the Centuries: Darwin's Ideas and Dmitry Belyaev's Long-Term Experiment in Silver Foxes, https://pdfs.semanticscholar.org/04b6/a404a156accd5bace6d97a830dda7703c686.pdf

- CASSIDY R., MULLIN M., Where the Wild Things Are Now: Domestication Reconsidered (Berg 2007)

- CLUBB R., MASON G.J., Natural behavioural biology as a risk factor in carnivore welfare: How analysing species differences could help zoos improve enclosures, Applied Animal Behaviour Science, 102/3 (2007) 303-328

- CLUTTON-BROCK J., A Natural History of Domesticated Mammals, Cambridge Univ. Press, Cambridge, UK (1999)

- CLUTTON-BROCK J., Animals as Domesticates, Michigan State University Press (2012)

- DANIELS TJ1, BEKOFF M., Feralization: The making of wild domestic animals, Behav. Processes, Jun; 19/1-3 (1989) 79-94

- DARWIN C., The origin of species (London 1859)

- DARWIN C., The Variation of Animals and Plants under Domestication (London 1868)

- DONALDSON S., KYMLICKA W., Zoopolis, A Political Theory of Animal Rights (Oxford 2011)

- DORNING J., HARRIS S., PICKETT H., The welfare of wild animals in travelling circuses (2016), https://www.ispca.ie/uploads/The welfare of wild_animals in travelling_circuses.pdf

- GAMBORG, C., CHRISTIANSEN, S.B., GREMMEN, B. \& SANDØE, P., De-domestication: ethics at the intersection of landscape restoration and animal welfare, Environmental Values 19/1 (2010) 5778. DOI: $10.3197 / 096327110 X 485383$

- GEPTS P., Plant and Animal Domestication as Human-Made Evolution, University of California, Davis, http://www.plantsciences.ucdavis.edu/gepts/Gepts\%20AIBS-NABT\%20Chicago\%202004.pdf

- PINILLOS, RG., APPLEBY, MC., MANTECA, X., SCOTT-PARK, F., SMITH, C., VELARDE, A., One Welfare - a platform for improving human and animal welfare, Veterinary Record 179 (2016) 412 413

- PRICE E.O., Behavioral aspects of animal domestication, Quarterly Review of Biology, 59 (1984) 132

- PRICE E.O., Behavioral development in animals undergoing domestication, Department of Animal Science, University of California, Davis, CA 95616-8521 USA (1999)

- PRICE E.O., Animal domestication and behaviour (New York 2002)

- REDFORD K.H., AMATO G., BAILLIE J., BELDOMENICO P., BENNETT E.L., CLUM N., COOK R., FONSECA G., HEDGES S., LAUNAY F., LIEBERMAN S., MACE G.M., MURAYAMA A., PUTNAM A., ROBINSON J.G., ROSENBAUM H., SANDERSON E.W., STUART S.N., THOMAS

\footnotetext{
${ }^{47}$ DONALDSON S., KYMLICKA W., Zoopolis, A Political Theory of Animal Rights (Oxford 2011)

${ }^{48}$ See supra, note 14

54 Derecho Animal. Forum of Animal Law Studies, vol. 10/2
} 
P., THORBJARNARSON J., What does it mean to successfully conserve a (vertebrate) species?, BioScience 61 (2011) 39-48

- RICKER J.P., SKOO L.A., HIRSCH J., Domestication and the behavior-genetic analysis of captive populations, Applied Animal Behaviour Science, 18 (1987) 91-103

- TRUT, L.N., Early canid domestication: the farmfox experiment, American Scientist 87 (March-April) (1999) 160-169, http://courses.washington.edu/anmind/Trut $\% 20$ on $\% 20$ the $\% 20$ Russian $\% 20$ fox $\% 20$ expt $\% 20$ \%20Amer\%20Sci\%201999.pdf

- TRUT, L., OSKINA, I., KHARLAMOVA, A., Animal evolution during domestication: the

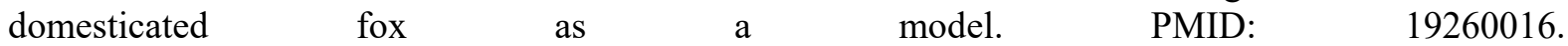
https://www.ncbi.nlm.nih.gov/pmc/articles/PMC2763232/

- TRUT LN, PLYUSNINA IZ, OSKINA IN. An experiment on fox domestication and debatable issues of evolution of the dog. Rus J Genetics. 40 (2004) 644-655. https://www.ncbi.nlm.nih.gov/pubmed/15341270

- SMIL V., Harvesting the Biosphere: The Human Impact, Population and Development Review, 37(4) : 613-636 (DecEM BER), (2011), http://vaclavsmil.com/wp-content/uploads/PDR37-4.Smil _.pgs613636.pdf

- WARWICK C., Reptilian ethology in captivity: observations of some problems and an evaluation of their aetiology, Applied Animal Behaviour Science, 26 (1990) 1-13

- WILKINS A.S., WRANGHAM R.W., TECUMSEH FITCH W., The "Domestication Syndrome" in Mammals: A Unified Explanation Based on Neural Crest Cell Behavior and Genetics, 197/3 Genetics (2014) 795-808

- CITES, Resolution Conf. 10.16 (Rev.), https://www.cites.org/eng/res/10/10-16C15.php

- Consolidated version of the Treaty on the Functioning of the European Union, Official Journal C 326 , 26/10/2012, P. 0001 - 0390 (13 December 2007)

- Convention on Biological Diversity (5 June 1992), https://www.cbd.int/doc/legal/cbd-en.pdf

- Regulation (EU) No 576/2013 of the European Parliament and of the council of 12 June 2013 on the non-commercial movement of pet animals and repealing Regulation (EC) No 998/2003

- Animal Health Law - Regulation (EU) 2016/429 of the European Parliament and of the Council of 9 March 2016 on transmissible animal diseases and amending and repealing certain acts in the area of animal health

- Eurogroup for Animals, Analysis of national legislation related to the keeping and sale of exotic pets in Europe (July 2013)

- Eurogroup for Animals, Statement on ethological needs and welfare of wild animals in circuses (September 2015)

- IUCN, Guidelines for Using the IUCN Red List Categories and Criteria, Version 13 (March 2017)

- OIE, The OIE Terrestrial Animal Health Code, Glossary (2017)

- One Health Initiative, http://www.onehealthinitiative.com/

- Online Etymology Dictionary, search keyword: domesticate, http://www.etymonline.com

- Online Oxford Dictionaries, search keyword: domesticated, http://www.oxforddictionaries.com/definition

- Online Oxford Dictionaries, search keyword: domestication, http://www.oxforddictionaries.com/definition

- Online Collins Dictionary, search keyword: domesticated, http://www.collinsdictionary.com

- Online Etymology Dictionary, search keyword: domestic, http://www.etymonline.com

- Online Oxford Dictionaries, search keyword: domestic, http://www.oxforddictionaries.com/definition

- Online Collins Dictionary, search keyword: domestic, http://www.collinsdictionary.com

- UNODC, World Wildlife Crime Report - Trafficking in protected species, United Nations Office on Drugs and Crime (2016), https://www.unodc.org/documents/data-andanalysis/wildlife/World Wildlife Crime Report 2016 final.pdf

- Wikipedia, The Free Encyclopedia, List of domesticated animals https://en.wikipedia.org/wiki/List_of_domesticated_animals 